\title{
展 インターロックト化合物の合成によるナノ林料の機能誩計
}

Functionality Design of Nano Materials by Synthesis of Interlocked Compounds

\author{
高田十志和・木 原 伸 浩・古 荘 義 雄
}

\begin{abstract}
ロタキサンやカテナンなどのインターロックト化合物は，分子マシンをはじめとするナノ 材料に必須不可欠のモチーフとして注目を集めている。本稿では，インターロックトユ ニットをもつナノ材料の設計指針について解説するとともに，その最近の展開について合 成的側面から研究を紹介し将来を展望する。
\end{abstract}

\section{1. はじめに}

自由度と運動性の高い機械的な結合を特徵と するイソターロックト化會物は, 分子モー ター, 分子スイッチなどのナノメートルサイズ の素子としてその機能が注目されてきたが，実 際分子素子, ナノ材料を志向した方向でロタキ サンやカテナンの応用研究が Stoddart らを中 心として進められている11。これらインター ロックト化合物合成の進歩は最近とくに著し く，合目的的な設計之高効率・高収率合成が同 時に達成されつつある。

高分子の立場からは, ポリロタキサンの構造 的な特徵を活かした素子の開発研究が進展しつ つある。基本的にはロタキサン，カテナン同様 ポリロタキサンにおける軸に対する輪（あるい はナノチューブ）の位置制御に基づくあのであ る。たとえば，伊藤らは，原田らが開発したシ クロデキストリンナノチューブ2) を導電性高分 子に被覆することで「分子被覆導線」として,
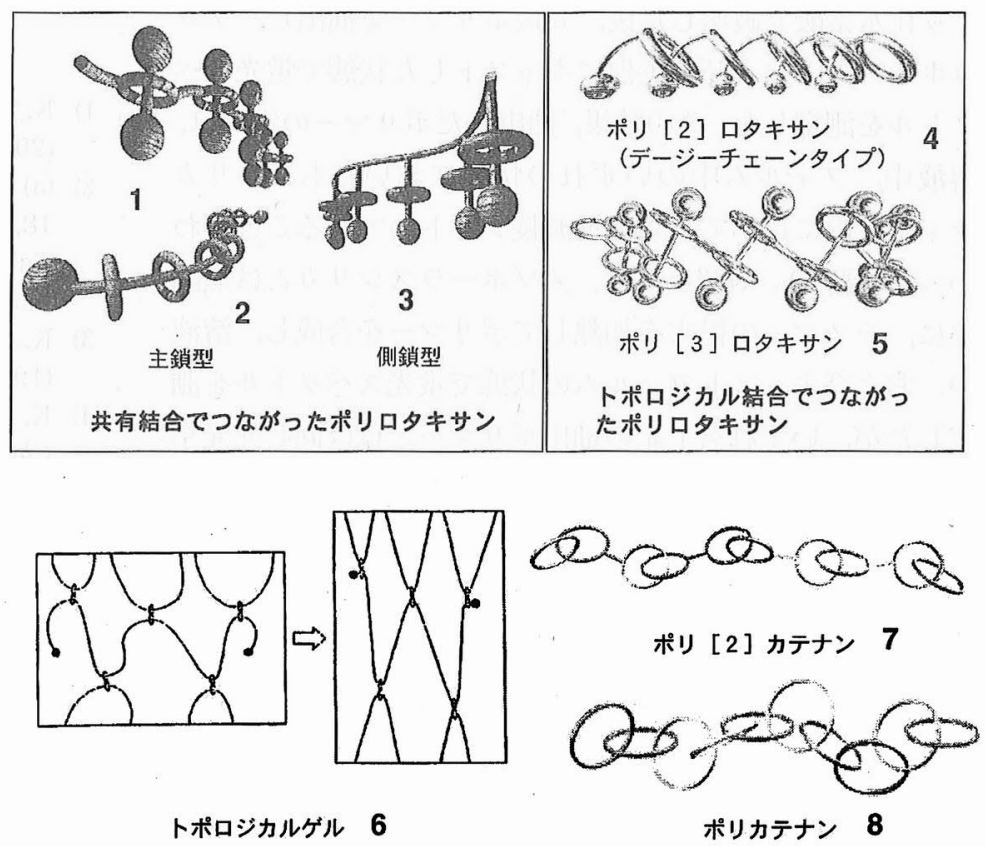

図 1 ポリロタキサン, トポロジカルゲル执よびポリカテナン

ナノメートルサイズの回路の組み立てが可能であることを 示しだ3。 また素材の観点では，これまで報告されたポリ ロタキサン $(1 \sim 3)$ はいずれ屯既存のポリマー構造を主鎖 にあつため, その特徴である空間結合に基づく特性をポリ マー全体の物性に活かすことはできない。ロタキサン構造 そのものがモノマー連結部位となったものでなければ，そ の特徵をポリマー物性に反映させることは不可能であろ う。したがって，現在のポリロタキサン合成における最大
のターゲットは，4や 5 である。実際にロタキサン構造で 高分子をつなぐことによって, 新しい素材が生まれてい る。伊藤らは, ポリエチレングリコールを 2 ないし 3 官能 性のシクロデキストリンでロタキサン構造形成による架橋 を行うと，一般の化学ゲルとは異なる新しいタイプのゲル (トポロジカルゲル，6）が得られることを報告している4)

一方, ポリ[2]カテナン (7) はいくつか報告されている5 が，完全に輪成分のみからなるポリカテナン $(8)$ はいまだ


Toshikazu TAKATA (写真左) 大阪府立大学大学院工学研究科（5998531 大阪府堺市学園町 1-1) ・教授, 理学博士.

1981年 筑波大学大学院博士課程修了. 専門は高分子合成, 有機合成 〈趣 味〉スポーツ (野球, テニス，柔道など）の実戦，観戦

Nobuhiro KIHARA (写真中)（同上）・助教授，博士（工学）.

1989年 東京大学大学院博士後期課程中退. 専門は高分子合成, 有機合成 〈趣味〉コントラバス

Yoshio FURUSHO (写真右) (同上) - 助手, 博士 (工学).

1995年 東京大学大学院工学系研究科中退. 専門は高分子合成, 有機合成 〈趣味〉魚釣り, 読書 
合成されていないため，この分野のあっとあ大きな標的分 子である。ポリ[2]カテナンでは, (i) 輪と輪の間に引力的な 相互作用がないこと，(ii) 輪と輪を結ぶつなぎの部分はで きるだけ剛直であること，ならびに (iii) 輪の分子量は 10,000 以上であること，が達成できれば特徽的な物性を 示す材料となりうる6)が，このようなポリマーはいまだ合 成されていない。実際，これまで報告されたポリ[2]カテナ ンには何ら特徵的な性質は見いだされていない。

本稿では，トポロジカルな結合が機能発現の鍵となるナ ノ材料の設計においてその基盤をなすインターロックト化 合物・ポリマーの最新の合成法について紹介する。

\section{2. ロタキサン・ポリロタキサン}

ホスト・ゲスト相互作用を利用したロタキサンのいわゆ る戦略的な合成法の発展には目を見張るあのがあり，最近 になって 9 割を超える収率でロタキサンを得る方法あい
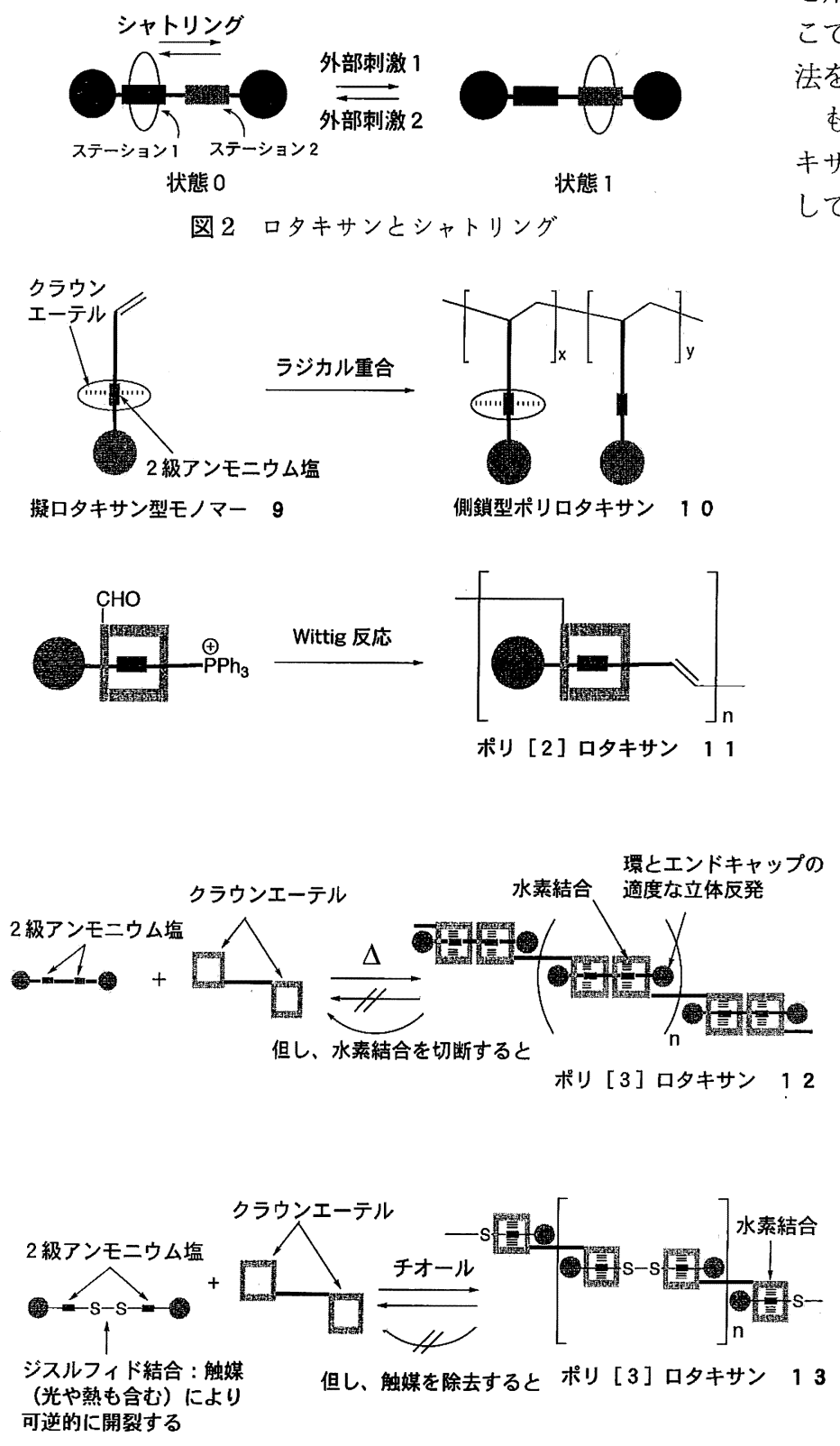

図 3 さまざまなポリロタキサンの合成法
くつか報告されているが，詳しくは他の総説にゆずる7)。 ロタキサンを機能性材料として展開していくに当たって考 えられる最大の特徵は, 輪成分が軸上を自由に運動（シャ トリング）できることである（図 2)。さらに，軸上に“ス テーション”を導入することで輪成分の位置を外部刺激な どによりコントロールすることも可能である。これに対し ては分子スイッチ，分子メモリや分子モーターといった分 子マシンとしての可能性が提唱されている8)。また，筆者 らはこのインターロックト構造を反応場としてとらえ, 口 タキサン型反応剤・触媒を検討しており, 最近不斉合成系 として有望であることを報告した ${ }^{9)}$ 。

一方，ロタキサンユニットを高分子へ導入することに よっても，さまざまな効果が期待できる。図 1 に示すよう に，導入位置に基づいて異なるトポロジーをむつポリロ夕 キサンを創製していくことが可能であるが，このトポロ ジーの違いによりポリロタキサンの性質は大きく変化す る。これまでポリロタキサンはおすにシクロデキストリン を用いて合成されてきたが，優れた総説があるので2)，こ こではとくにクラウンエーテルをべースとするあのの合成 法を中心に述べる。

あっとあオーソドックスなタイプである主鎖型ポリロ夕 キサンは数多く合成されているが, クラウンエーテルに関 してはとくに H. W. Gibson らにより精力的に検討されて いる10)。筆者らは，クラウンエーテルが水素結合を 介して 2 級アンモニウム塩を強く包接することを 利用して ${ }^{11)}$ ，末端にビニル基をもつラジカル重合性 擬ロタキサンモノマー(9) を設計し，そのラジカル 重合により側鎖型ポリロタキサン $(\mathbf{1 0})$ を合成し た ${ }^{12)}$ (図 3)。この方法論では他のビニルモノマーと の共重合む可能であり，またモノマーの仕込み比だ けでなく, 溶媒, 温度などによりクラウンェーテル の導入率を容易に制御することが可能である。

最近ようやく主鎖が機械的結合からなる新しい夕 イプのポリロタキサンが合成され始めた。Stoddart らはエンドキャップと環上に反応性官能基をむつ [2]ロタキサンの重縮合によりポリ[2]ロタキサン (11)を合成した ${ }^{13)}$ 。筆者らは, 環成分とエンド キャップのサイズ相補性を利用したスリッピング法 を 2 官能性化合物に応用したポリスリッピング法 を開発し，ポリ[2]ロタキサン(12)を合成した14)。 本方法はいわゆる平衡重合系であり, 重合度は系の 熱力学的安定性によって決まる。12 は環成分と工 ンドキャップの適度な立体反発と水素結合の「二重 ロック」により安定化されているため, 室温では十 分に安定であるが，DMSOのような高極性溶媒を 用いて安定化因子のひとつである水素結合を切断す ることで, 定量的にモノマーへ変換することが可能 である。

筆者らはまた，ジスルフィド基の可逆的な開裂再結合プロセスを利用したロタキサン合成法をむと に ${ }^{15)}$ ， ポリ[3]ロタキサン (13)を合成した ${ }^{16)}$ ○の 系も触媒存在下では平衡重合系であるため, 重合条 
件により分子量をコントロールすることが可能であり，モ ノマーへのリサイクルあ容易である。あちろん，触媒を除 くことにより構造を完全にロックすることができる。

これらの 2 つ方法論は重合過程において余分な物質 を排出することのない「古典的」な重付加に相当する。重 付加の場合, 共有結合の生成・切断を伴うためエネルギー の収支が大きく, 環境に多大な負担をかけている。一方, 筆者らの方法は, 重合あるいは解重合過程におけるトー夕 ルでの共有結合の生成または切断はないのでエネルギー収 支屯小さく，環境調和型のグリーンケミストリー的重合法 となりうる。また, 新しいタイプのリサイクルポリマーと してあ有望である。

以上のように，さまざまなトポロジーと特性をむつポリ ロタキサンを合成することが可能になってきたが，さらに ステーションなどを導入すれば外部刺激による機能の制御 が可能になるため，ケモメカニカルアクチュエーターなよ゙ の強相関ソフトマテリアルむ可能になってくるあのと期待 される。一方, これとは逆に環成分と軸上に存在する水素 結合などの引力的相互作用を除去することで, 環成分の運 動性を可能な限り大きくし， ロタキサンユニットの性質を ポリロタキサンの粘弾性や力学的物性により反映させるこ とができるようになる17)。

\section{3. カテナン, ポリカテナン}

カテナンの合成もロタキサンの合成と同様に, 各コン ポーネントの前駆体を自己集合により集積しておき，最後 にカテナン構造を固定することで行われる（図 4)。しか し，カテナンとロタキサンでは大きな違いがある。ロタキ サンの合成においては，環構造を最初からつくっておく方 法と, 最後に環化する方法とがあるが, カテナン構造を構 築する場合には, 最後の反応は必ず環化になる。一般に自 己集合は高濃度で有利であるのに対して環化反応は低濃度 で有利であるから，カテナンの合成はロタキサンの合成に 比べてずっと困難である。したがって, 効率的にカテナン を合成するためには，低濃度でも平衡が自己集合側に傾い た組織系を利用するか，高濃度でも重合せずに環化する系 を利用する必要があり，とくに前者のアプローチが効果的
である。水素結合を利用する系は，市販の試薬を混合する だけであカテナンが合成できるので, 得られるカテナンは さまざまなカテナンの原料としてあ利用できる7)。

筆者らは， $p$-キシリレンジアミンとイソフタル酸クロリ ドを混合しただけで合成できるカテナン $(\mathbf{1 4})$ を用いてさ まざまな官能基を有するカテナンの合成を検討した17) (図 5)。14をDMSO 中で水酸化カリウムとヨウ化メチル で徹底的にアルキル化すると,オクタメチル体 (15) が高収 率で得られた。また，14および 15 を徹底ボラン還元した ところ, アミン型のカテナン $(16,17)$ がそれぞれ得られ た。カテナンの官能基をこのように変換していくと, 輪が 互いの周りを回転する速度が劇的に変化する。なお，16 は カテナン構造を有するポリアミンという，たいへん興味あ る化合物である。

カテナン (catenane) の名が鎖を意味するラテン語 catenaに由来するとおり，カテナン構造を主鎖に有する ポリカテナン $(8)$ には鎖のような高度の屈曲性と特殊な伸 縮特性が期待できる。前述のように主鎖型のポリカテナン には大きく分けて 2 種類ある。ひとつは [2]カテナン構造 を組み込んだモノマーを重合することで得られるポリ[2] カテナン (7)であり，あうひとつはポリカテナン $(8)$ である。 重合法としては，これまでおあに二官能性の[2]力テナ ンを用いた重縮合・重付加反応が検討されてきた。ここで は文献をあげるにとどめ5)，詳細は割愛する。ポリカテナ ン (8) ではカテナンとしての性質が十分に発揮されると期 待されているが, その合成は容易ではない。たとえば,

図 6 I のような自己集合状態にあるモノマーを用いて官能 基 A どうしの結合により重合しようとすると, 環化の効 率は $100 \%$ に達しないから, 必ず分岐構造が入ってきてし まい，そこでカテナン構造が途切れてしまう（図 6)。した がって，ポリカテナン鎖を合成するには，ポリペプチド合 成のように段階的に環をつなげていくか, 効率 100\%の環 化反応を利用するしかない。

段階的に環をつなげていく方法は，鎖が長くなるにつれ て急速に収量が低下していくことが問題である。現在，鎖

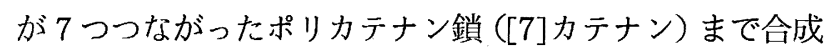
されているが18), これは分岐構造を含んでおり，直鎖状の あのとしては [5]カテナン（その構造から Olympiadane

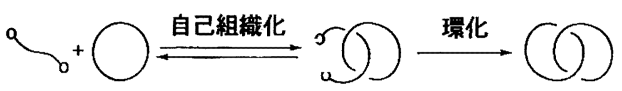

図4 カテナンの合成戦略

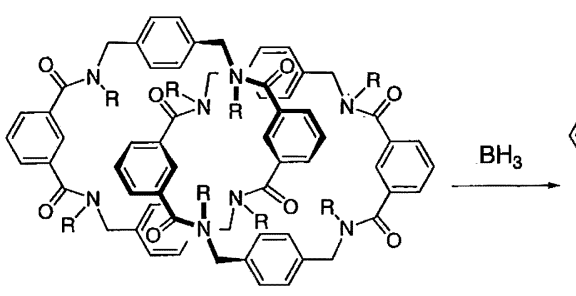

$\begin{array}{rl} & 14(\mathrm{R}=\mathrm{H}) \\ \mathrm{Mel}, \mathrm{KOH} & 15(\mathrm{R}=\mathrm{Me})\end{array}$

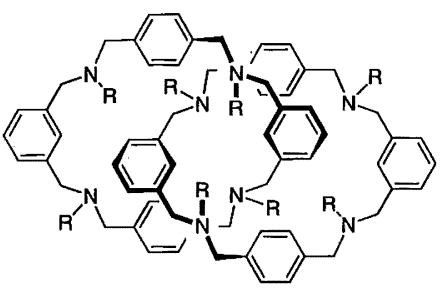

$16(R=H)$
$17(R=M e)$



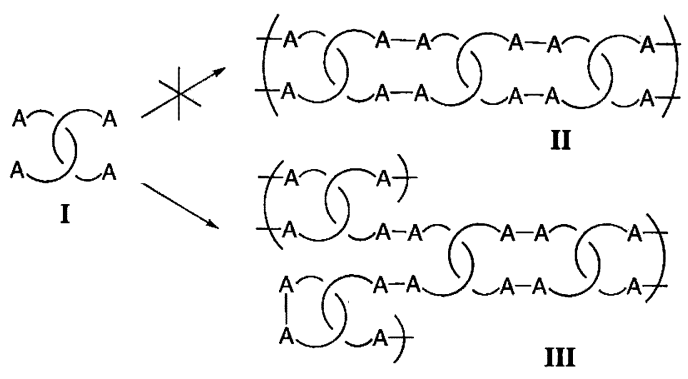

図 6 環化反応によるポリカテナンの合成

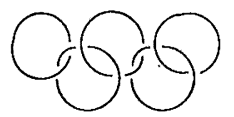

図 7 Olympiadane 
と名づけられた）が最長のものである ${ }^{19)}$ (図 7)。

一方，効率 100\% の環化反応があれば，原理 的にカテナン鎖の合成が可能となる。そのよう な反応としてたとえば Diels-Alder 反応をあげ ることができる。すなわち，Diels-Alder 反応 で 2 点を同時に結んだ後，邪魔な結合を断ち切 ることができればカテナン鎖が合成できよう (図 8)。この方法によるポリカテナン鎖の合成 はまだ実現されていないが，筆者らはこのテス トケースとして，カテナンの環拡大反応を行っ た20)。すなわち，1,3-ジェンをスルホレンで保
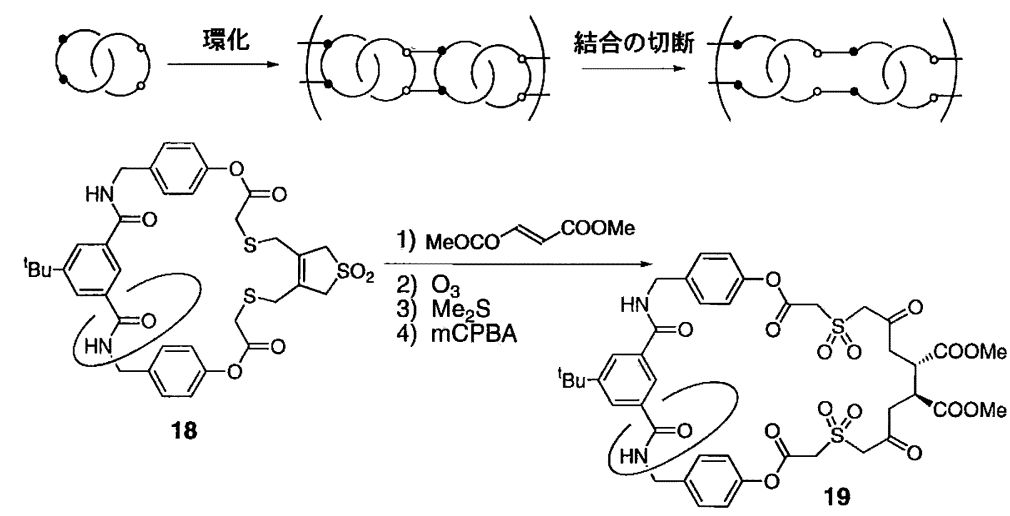

図 8 Diels-Alder オゾン分解によるポリカテナンの合成戦略

護したカテナン $(\mathbf{1 8})$ をジエノフィルとDiels

Alder 反応し，オレフィンをオゾン分解したところで環拡 大したカテナン (19) が得られ，環がちぎれたような生成物 は得られなかった。このことは，本方法論が本質的にポリ カテナン鎖合成に適していることを示している。一般に, ラダーポリマーの合成法はカテナン鎖の合成に応用するこ とができ，この方法論によってはじめてのポリカテナン 8 が得られる日も近いと期待される。

\section{4. おわりに}

インターロックト化合物の「物理的」な応用がしばしば 強調されているが，もっと「化学的」な側面にも注目すべ きである。本文中であ一部紹介したが，共有結合でも配位 結合であない比較的自由な空間結合でいくつかのコンポー ネントを結びつけると，その協同効果はこれまでにわれわ れが経験したことのない, 新しい“反応場・認識場”をつ くりだす可能性がある。また, インターロックトシステム をうまく利用すれば有機化学反応の機構を研究するうえで の probeともなりうる。

高分子の観点からは，輪成分の分子量をいかに高く制御 できるかにかかっている。現在の有機合成技術では，分子 量が 10,000 の環状化合物を得ることは不可能である。 キャラクタリゼーションなどの問題はあるが，高分子とし てある分布をもった環状 “ポリマー”であれば，亀山ら ${ }^{211}$ や尾池ら ${ }^{22)}$ の手法で合成可能になる。インターロックトシ ステムをこのような“ポリマー”であつくりあげることが できれば，これまでに類を見ない「高分子新素材」として 位置づけることもできよう。

いずれにしてあ，こうしたインターロックト分子・ポリ マーは, 物理的・化学的両側面でナノメートルサイズのユ ニークな素子・素材を提供する夢のある研究を約束してく れる分子群である。今後の展開が非常に楽しみであるが, やはりそれには普遍的で応用範用の広い合成法の確立が不 可欠である。ここまで進歩しても，いまだに「合成困難な 物質」のレッテルを奴うことができないのは残念である ので。

\section{文 献}

1) R. Dagani: $C \& E N, 78(42), 25$ (2000)

2) A. Harada: In "Large Ring Molecules," J. A. Semlyen, Ed., Wiley, Chichester (1996), pp. 407-432

3）伊藤耕三，下村武史：化学と工業， 52,1170 (1999)

4) K. Ito, Y. Okumura: Adv. Mater., 13, 485 (2001)

5) F. M. Raymo, J. F. Stoddart: Chem. Rev., 99, 1643 (1999); J. -L. Weidmann, J.-M. Kern, J.-P. Sauvage, D. Muscat, S. Mullins, W. Kohler, C. Rosenauer, H. J. Rader, K. Martin, and Y. Geerts: Chem. Eur. J., 5, 1841 (1999)

6). 岩田一良: 私信

7) 木原伸浩, 高田十志和：有機合成化学協会誌，59, 206 (2001)

8) J. F. Stoddart: Acc. Chem. Res., 34, 410 (2001)

9) Y. Tachibana, Y. Ohga, N. Kihara, and T. Takata: Chem. Lett., 806 (2000)

10) H. W. Gibson: In "Molecular Catenanes, Rotaxanes and Knots," ed. by J.-P. Sauvage and C. Dietrich-Buchecker, Wiley-VCH, Weinheim (1999), pp. 277-311

11) P. T. Glink, C. Schiavo, J.F. Stoddart, and D. J. Williams: Chem. Commun., 1483 (1996)

12) T. Takata, H. Kawasaki, S. Asai, N. Kihara, and Y. Furusho: Chem. Lett., 111 (1999); T. Takata, H. Kawasaki, N. Kihara, and Y. Furusho: Macromolecules, 34, 5449 (2001)

13) S. J. Rowan, S. J. Cantrill, J. F. Stoddart, A. J. P. White, and D. J. Williams: Org. Lett., 2, 759 (2000)

14) Y.-h. Sohgawa, H. Fujimori, J. Shoji, Y. Furusho, N. Kihara, and T. Takata: Chem. Lett., 774-775 (2001)

15) Y. Furusho, A. Tsuboi, T. Hasegawa, N. Kihara, and T. Takata: Chem. Lett., 18 (2000)

16）奥 智也, 古荘義雄, 高田十志和：予稿集， 50, 318 (2001)

17) T. Takata, J. Shoji, and Furusho: Chem. Lett., 881 (1997). N. Watanabe, Y. Furusho, N. Kihara, and T. Takata: Chem. Lett., 915 (1999); Y. Furusho, J. Shoji, N. Watanabe, N. Kihara, T. Adachi, and T. Takata: Bull. Chem. Soc. Jpn., 74, 139 (2001); N. Watanabe, Y. Furusho, N. Kihara, T. Takata, K. Kinbara, and K. Saigo: Bull. Chem. Soc. Jpn., 74, 149 (2001)

18) D. B. Amabilino, P. R. Ashton, V. Balzani, S.E. Boyd, A. Credi, J. Y. Lee, S. Menzer, J. F. Stoddart, M. Venturi, and D. J. Williams: J. Am. Chem. Soc., 120, 4295 (1998)

19) D. B. Amabilino, P. R. Ashton, A. S. Reder, N. Spencer, and J. F. Stoddart: Angew. Chem. Int. Ed. Engl., 33, 1286 (1994)

20) N. Watanabe, N. Kihara, and T. Takata: Org. Lett., in press.

21) A. Kameyama, Y. Murakami, and T. Nishikubo: Macromolecules, 32, 1402 (1999)

22) H. Oike, S. Kobayashi, T. Mouri, and Y. Tezuka: Macromolecules, 34, 2742 (2001) 